\title{
Magnetic and Mesoporous Silica-Niobia Material as Modifier of Carbon Paste Electrode for $\boldsymbol{p}$-Nitrophenol Electrochemical Determination
}

\author{
Oleg Tkachenko, ${ }^{\oplus *, a, b}$ Danielle S. da Rosa, ${ }^{\oplus a}$ Anike H. Virgili, ${ }^{\oplus a}$ \\ Marcos A. Z. Vasconcellos, ${ }^{\oplus c}$ Tania M. H. Costa, ${ }^{\circledR a}$ Leliz, T. Arenas, ${ }^{\oplus a}$ \\ Monique Deon, ${ }^{\circledR a}$ Edilson V. Benvenutti ${ }^{\circledR a}$ and Eliana W. de Menezes ${ }^{\circledR} * a$ \\ ${ }^{a}$ Instituto de Química, Universidade Federal do Rio Grande do Sul (UFRGS), CP 15003, \\ 91501-970 Porto Alegre-RS, Brazil \\ ${ }^{b}$ Materials Chemistry Department, V. N. Karazin Kharkiv National University, \\ 4 Svoboda Square, 61022 Kharkiv, Ukraine \\ cInstituto de Física, Universidade Federal do Rio Grande do Sul (UFRGS), \\ CP 15051, 91501-970 Porto Alegre-RS, Brazil
}

\begin{abstract}
In the present work, the sol-gel synthesis method was employed as strategy to obtain a magnetic and mesoporous silica-niobia material. The planned synthesis was based on the heterocondensation of niobium and silicon alkoxide precursors, in the presence of spherical magnetite particles. The resulting material presented interesting characteristics such as magnetism, large mesopores, in the range from 20 to $50 \mathrm{~nm}$, and $68 \mathrm{~m}^{2} \mathrm{~g}^{-1}$ of surface area. These features allowed its use as modifier of carbon paste electrode for $p$-nitrophenol determination, since niobia has never been used in electrochemical sensors for the determination of nitrophenol compounds. By using differential pulse voltammetry technique, the electrode can be applied in a wide range of p-nitrophenol concentration, from 10 to $490 \mu \mathrm{mol} \mathrm{L}{ }^{-1}$, with a limit of detection of $1.2 \mu \mathrm{mol} \mathrm{L}-1$ and sensitivity up to $0.60 \mu \mathrm{A} \mathrm{L} \mu \mathrm{mol}^{-1}$. The proposed electrode presented good sensitivity and selectivity and it was applied in real water samples.
\end{abstract}

Keywords: composite, $\mathrm{SiO}_{2}, \mathrm{Nb}_{2} \mathrm{O}_{5}, \mathrm{Fe}_{3} \mathrm{O}_{4}$, 4-nitrophenol, environmental pollutant

\section{Introduction}

Phenolic compounds play significant physiological and biochemical roles in living systems. In addition, they are widely used in industrial activities such as polymer production, paper pulp, pesticides, drugs and other products. ${ }^{1-3}$ The accumulation of phenolic compounds in the environment, ${ }^{4}$ as a product of intensive human activity, may result in serious ecological problems, ${ }^{1,5}$ because they present low degradability. Therefore, the monitoring of phenolic compounds, as well as their detection methods and decomposition are highly relevant in environmental sciences.

Among the phenolic compounds, $p$-nitrophenol ( $p$-NP) is a precursor of several pollutants. It is widely known as a carcinogen and it tends to persist in soil and water. ${ }^{6}$ Therefore, the $p$-NP concentration has been used as a standard of quality for waters by many countries.?

\footnotetext{
*e-mail: oleg.s.tkachenko@karazin.ua; eliana.weber@ufrgs.br
}

Several analytical methods have been employed for the detection/quantification of nitrophenol compounds, such as high-performance liquid chromatography, fluorescence detection, capillary electrophoresis, spectrophotometry and electrochemical methods. ${ }^{7-10}$ Among these, the electrochemical methods that use modified electrodes have been attracting much attention since they involve simple operation processes with low cost, also they are sensitive and accurate, and the experiments can be performed in real time. ${ }^{7,10,11}$

Among the eligible electrodes, the carbon paste ones (CPEs) have been widely used in the development of sensors due to their easy construction by mixing graphite powder and mineral oil. Additionally, they present renewable surface, compatibility with several modifiers, ${ }^{12-14}$ offer a wide range of working potential as well as low background current. ${ }^{15,16}$ Despite these advantages, the addition of different species on CPEs still needs to be improved, mainly from the standpoint of stability and reproducibility. ${ }^{17}$ 
The modification of CPEs with mesoporous materials, such as silica, allows a homogeneous dispersion of the components, providing interesting properties, such as increase in the electroactive area, greater diffusion of the analytes into the matrix, mechanical resistance and chemical stability. ${ }^{18,19}$ Additionally, the presence of silanol groups on the silica surface permits the addition of functional groups or electroactive species. ${ }^{15,20}$ However, in order to minimize the electrical resistance of the silica and enhance the performance of CPEs, other metal oxides, such as titania, ${ }^{21,22}$ niobia, ${ }^{23-25}$ ceria ${ }^{26}$ or magnetite ${ }^{27,28}$ have been also added. The use of these metal oxides is due to their low band gap energy, ${ }^{29-32}$ and also due to their Brønsted and Lewis acidity, which allows interactions with several organic species. ${ }^{33-35}$

Although electrochemical sensors based on silica ${ }^{36-38}$ or titania ${ }^{39}$ have been reported for nitrophenols determination, as far as we know electrochemical sensors based on niobia, for the determination of these compounds, were not reported. Therefore, in this work, a CPE was modified with magnetic silica-niobia material (MP@SiNb), obtained by sol-gel method, using silicon and niobium molecular precursors and magnetite particles (MP). The modified CPE (MP@SiNb-CPE) was applied for $p$-nitrophenol determination using differential pulse voltammetry.

\section{Experimental}

Synthesis of magnetite particles coated with silica $\left(\mathrm{MP} @ \mathrm{SiO}_{2}\right)$

The synthesis of MP was made by solvothermal method, employing $\mathrm{FeCl}_{3} \cdot 6 \mathrm{H}_{2} \mathrm{O}$ (Vetec, Duque de Caxias, Brazil, 97\%) as precursor and ethylene glycol (Merck, Darmstadt, Germany, 99.5\%) as both solvent and reducing agent. The procedure was already reported. ${ }^{40}$ The shell of silica was prepared based on a previous work, ${ }^{41}$ using an adapted Stöber method, which employs ammonia as gelation catalyst. The magnetite particles $(330 \mathrm{mg}$ ) were added to a mixture containing $25 \mathrm{~mL}$ of water, $100 \mathrm{~mL}$ of ethanol (Merck, Darmstadt, Germany, 99.9\%) and $3.0 \mathrm{~mL}$ of ammonia solution (Merck, Darmstadt, Germany, 25\%) and submitted to ultrasonic bath $(1 \mathrm{~h})$. Subsequently, tetraethyl orthosilicate (TEOS, Sigma-Aldrich, St. Louis, USA, $0.730 \mathrm{~mL}$ ) was added. The system was submitted to ultrasound for additional 2 h. After washing and drying, the material was assigned as $\mathrm{MP} @ \mathrm{SiO}_{2}$.

\section{Synthesis of magnetic silica-niobia xerogel (MP@ $@ \mathrm{SiNb})$}

The xerogel containing silica, niobia and magnetite was obtained by using the sol-gel synthesis method. Firstly, three separated systems were prepared: $(i)$ a niobium ethoxide solution by dissolving $\mathrm{NbCl}_{5}$ (Sigma-Aldrich, St. Louis, USA, $3.1 \mathrm{mmol}$ ) in $1 \mathrm{~mL}$ of ethanol, under inert atmosphere; (ii) a mixture containing TEOS (Sigma-Aldrich, St. Louis, USA, $6.4 \mathrm{mmol}$ ), ethanol (Merck, Darmstadt, Germany, 99.9\%, $1.15 \mathrm{~mL}$ ), water $(0.22 \mathrm{~mL})$ and concentrated $\mathrm{HCl}$ (Merck, Darmstadt, Germany, 37\%, $0.14 \mathrm{~mL}$ ) kept under stirring for $1 \mathrm{~h}$ and; (iii) a suspension of $\mathrm{MP} @ \mathrm{SiO}_{2}(0.8 \mathrm{~g})$ in ethanol (Merck, Darmstadt, Germany, 99.9\%, 1.5 mL). The systems $(i)$ and (ii) were added to the system (iii) under stirring, followed by addition of HF solution (Merck, Darmstadt, Germany, 40\%, $0.9 \mathrm{~mL}$ ) and kept to gelation for $72 \mathrm{~h}$ at $25^{\circ} \mathrm{C}$. The formed solid was then powdered, washed with water followed by ethanol (Merck, Darmstadt, Germany, 99.9\%), and dried under vacuum, at ambient temperature, for $2 \mathrm{~h}$.

\section{Materials characterization}

Scanning electron microscopy (SEM) images were acquired using Zeiss Auriga microscope. The samples were dispersed in a conductive tape on aluminum support and coated with Au film. The average size of magnetite particles was estimated by using the Quantikov software. X-ray diffractogram was obtained using a Shimadzu XRD 6000 diffractometer, using $\mathrm{Cu} \mathrm{K} \alpha$. Magnetism was studied in EZ9 MicroSense magnetometer (vibrating sample magnetometer (VSM)) using magnetic field $(\mathrm{H})$ cycled between -22 and $+22 \mathrm{kOe}$. The $\mathrm{N}_{2}$ isotherms were acquired at $77 \mathrm{~K}$, using a Tristar II $\mathrm{Kr}$ Micromeritics equipment, after the samples degassing at $60{ }^{\circ} \mathrm{C}$, for 24 h. Brunauer-Emmett-Teller (BET) surface area and Barrett-Joyner-Halenda (BJH) pore size distribution methods were applied. ${ }^{42}$ The elemental analysis by energy dispersive spectroscopy (EDS) was performed by using a Jeol LV5800 SEM microscope. Disks of the materials were previously compacted at 4.5 ton $\mathrm{cm}^{-2}$, and then coated with carbon.

\section{Electrochemical measurements}

Cyclic voltammetry (CV) and differential pulse voltammetry measurements were performed on IviumStat galvanostat/potentiostat for analysis of $p$-NP (Vetec, Duque de Caxias, Brazil). The applied potential range was from -0.3 to $-1.0 \mathrm{~V}$. The system was stirred for $60 \mathrm{~s}$ followed by additional $60 \mathrm{~s}$ of rest time, before each measurement. The following parameters were applied: $100 \mathrm{mV}$ of pulse amplitude, $10 \mathrm{~ms}$ of pulse time, $0.01 \mathrm{~V} \mathrm{~s}^{-1}$ of scan rate and $1 \mathrm{mV}$ of potential step. The used three-electrode cell is constituted by: a silver/silver chloride electrode 
as reference; a platinum wire as auxiliary electrode; and the working electrode. All measurements were carried out at ambient temperature $\left(20{ }^{\circ} \mathrm{C}\right)$ in $0.04 \mathrm{~mol} \mathrm{~L}^{-1}$ of Britton-Robinson buffer (BRbs) solution, using $\mathrm{NaNO}_{3}$ (Dinâmica, Indaiatuba, Brazil, $0.5 \mathrm{~mol} \mathrm{~L}^{-1}$ ) as supporting electrolyte. All measurements were performed after $5 \mathrm{~min}$ of $\mathrm{N}_{2}$ bubbling, and during the measurements the $\mathrm{N}_{2}$ flux remained over the cell content. The MP@SiNb material was employed to modify carbon paste electrode (CPE) to be used as working electrode. The optimal composition of the CPE, which will be discussed later, was MP@SiNb material $(9 \mathrm{mg})$, graphite $(11 \mathrm{mg})$ and mineral oil $(5 \mathrm{mg})$. The components were thoroughly mixed, and a fraction of the paste was deposited in a Teflon cavity with $1 \mathrm{~mm}$ depth, connected to platinum disk (4 $\mathrm{mm}$ of diameter) glued to a glass tube with a copper wire. The prepared electrode was assigned as MP@SiNb-CPE. Also, CPE modified with $\mathrm{MP} @ \mathrm{SiO}_{2}$, as well as unmodified CPE were used for comparison, and they were called as $\mathrm{MP} @ \mathrm{SiO}_{2}-\mathrm{CPE}$ and unmodified-CPE, respectively. The working electrodes were cleaned by means of CV scanning in BRbs solution, in the same applied potential range, after each assay.

\section{Results and Discussion}

A magnetic silica-niobia material (MP@SiNb) was obtained by using the sol-gel synthesis method, which is based on the hydrolysis and condensation of molecular precursors. Silicon and niobium alkoxide precursors were employed along with MP coated with a silica shell $\left(\mathrm{MP} @ \mathrm{SiO}_{2}\right)$. The X-ray diffractograms of MP, MP@ $\mathrm{SiO}_{2}$ and MP@SiNb materials, which are presented in Supplementary Information (Figure S1), confirm the presence of facecentered cubic of inverse spinel structure of magnetite (JCPDS 19-0629), indicating that the silica shell and the silica-niobia xerogel growth did not disturb the magnetite crystalline structure. The new wide peaks that appear in the MP@SiNb material were interpreted as consequence of a new phase formed during the gelation process. This behavior was already reported ${ }^{43}$ for silica-titania xerogels, and they were attributed to ammonium oxofluorotitanate derivative phase, since the gelation process occurs in the presence of the ammonium and fluoride as catalyst.

The SEM images of the MP@SiNb material are presented in Figure 1, along with the SEM images of the MP and $\mathrm{MP} @ \mathrm{SiO}_{2}$ intermediate materials. Spherical particles of magnetite are clearly seen in the MP images (Figure 1a). The average diameter of these particles was estimated by applying the Quantikov software. The obtained value was $334 \mathrm{~nm}$ with $78 \mathrm{~nm}$ of standard deviation, for a population of 843 particles. The $\mathrm{MP} @ \mathrm{SiO}_{2}$ images, which are shown in Figure 1b, reveal that the modification with the silica shell produces more aggregated magnetite particles with smoother surface. The images of MP@SiNb material (Figure 1c) show that a xerogel moiety was successfully obtained and the magnetite particles are embedded in it. The elemental analyses of the MP@SiNb material (in oxide wt.\%) were performed by EDS analysis, using five different regions of the sample. The obtained average values were $\mathrm{Fe}_{3} \mathrm{O}_{4}$ (24.7 wt.\%); $\mathrm{SiO}_{2}\left(41.8\right.$ wt. \%) and $\mathrm{Nb}_{2} \mathrm{O}_{5}$ (33.5 wt.\%). The results of the five analyses, in different regions of the sample, are presented in the Supplementary Information (Table S1).

The magnetization of the materials was obtained from the plot of magnetic field $v s$. non-normalized magnetization that is shown in the Supplementary Information (Figure S2). The saturation magnetization decreases in the following order: MP, MP@ $\mathrm{SiO}_{2}$ and MP@SiNb. This feature is due to the incorporation of non-magnetic silica shell and subsequent non-magnetic silica-niobia mass to the system. However, even after the last modification (MP@SiNb material) the system remains magnetic.

The $\mathrm{N}_{2}$ adsorption-desorption isotherms and the BJH pore distribution curves of the materials are depicted in Figure 2. The BET surface areas and pore volumes are summarized in Table 1. Firstly, a decrease in the porosity can be seen after the silica shell is formed (MP to $\mathrm{MP} @ \mathrm{SiO}_{2}$ ), through a reduction in the amount of adsorbed nitrogen (Figure 2 insets) as well as a decrease in the surface area and in the pore volume were observed (Table 1). This behavior was already reported ${ }^{41}$ for magnetite/silica core/shell system, and the interpretation takes into account that the nonporous silica coating blocks the nitrogen gas access to both the interstitial spaces and the defects of magnetite crystalline packing, which were accessible before the silica shell formation. After the incorporation of silica-niobia xerogel moiety (MP@SiNb material), the porosity increases drastically. The isotherms of the MP@SiNb material show larger amounts of nitrogen adsorbed in high relative $P / P_{0}$ pressures (Figure 2a). In fact, the pore size analysis of MP@SiNb material, which is shown in Figure $2 b$, reveals a mesoporous profile,,$^{42}$ with a broad size distribution with maximum around $30 \mathrm{~nm}$. The increase in the porosity for MP@SiNb material is also confirmed by its higher surface area and pore volume values presented in Table 1. These features, such as magnetism and porosity, make the MP@SiNb material suitable to be applied as matrix for the construction of modified carbon paste electrodes (CPE). ${ }^{27,44}$

The MP@SiNb material was used to modify CPE and to investigate the electrochemical reduction of $p$-NP by means of voltammetric techniques. The obtained CVs 


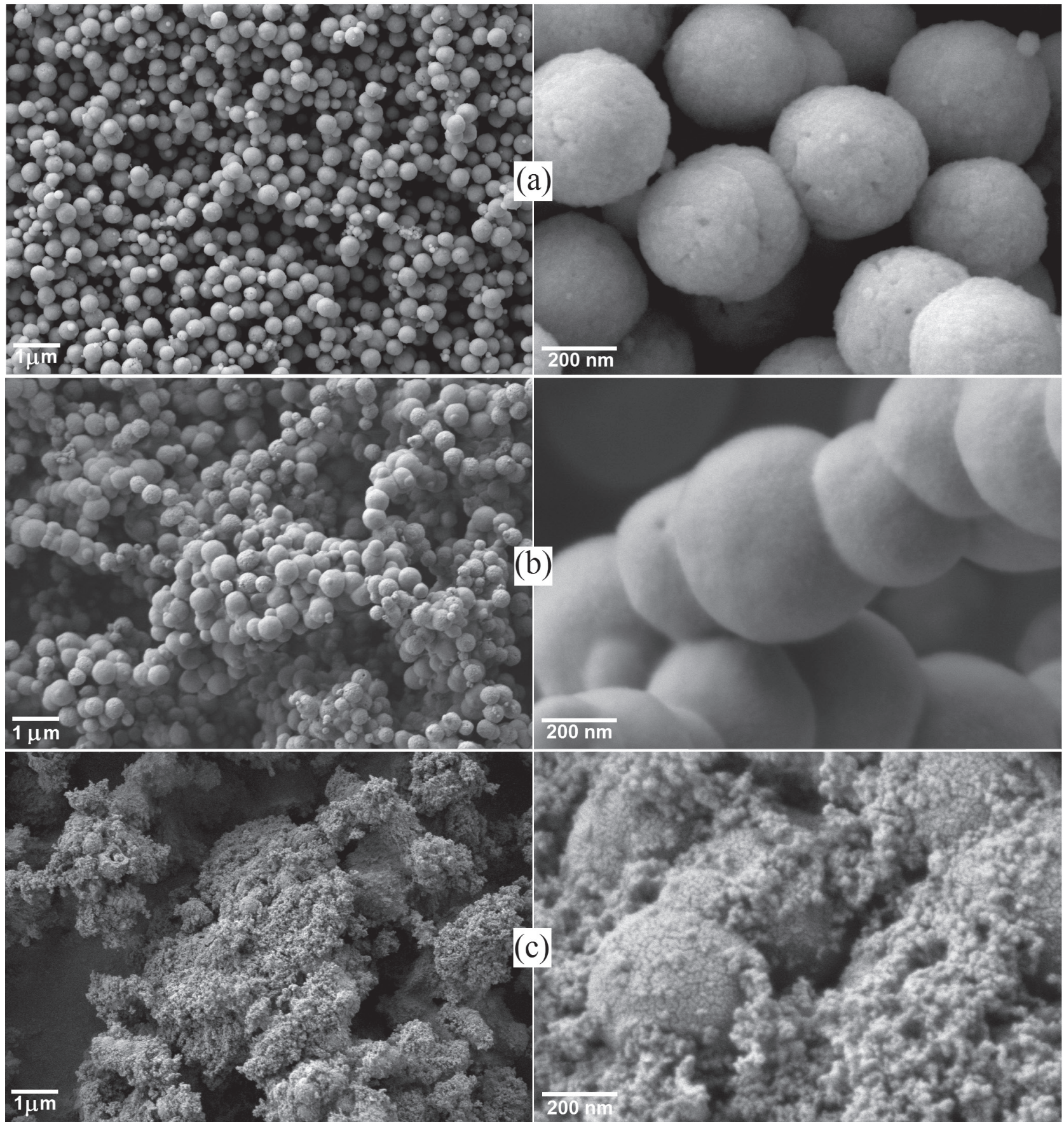

Figure 1. SEM images obtained at different magnifications 10,000 and 80,000×. (a) MP; (b) $\mathrm{MP} @ \mathrm{SiO}_{2}$ and (c) MP@SiNb materials.

are presented in Figure S3 (Supplementary Information). The electrodes of all materials did not demonstrate redox reactions within studied potential range, in the absence of $p$-NP. At the same time, addition of $p$-NP $\left(148 \mu \mathrm{mol} \mathrm{L} \mathrm{L}^{-1}\right)$ resulted in appearance of reduction peak of $p$-NP for all material electrodes. However, the MP@SiNb-CPE presented higher cathodic peak current $(-29.1 \mu \mathrm{A})$ and lower peak potential $(-0.69 \mathrm{~V})$ when compared to unmodified-CPE $(-6.0 \mu \mathrm{A}$ and $-0.88 \mathrm{~V}$, respectively).
The obtained differential pulse voltammetry, which is presented in Figure 3, shows that the modified electrode (MP@SiNb-CPE) exhibits higher cathodic peak current $(-33.2 \mu \mathrm{A})$ and less negative potential value $(-0.64 \mathrm{~V})$ when compared with MP@ $\mathrm{SiO}_{2}-\mathrm{CPE}(-20.7 \mu \mathrm{A},-0.74 \mathrm{~V})$ or with unmodified-CPE $(-11.9 \mu \mathrm{A},-0.77 \mathrm{~V})$. The electrochemical behavior of MP@SiNb-CPE was interpreted by means of several features. The presence of magnetite that has low band gap energy, which depends on its particle size, ${ }^{32,45}$ has been recognized as signal-amplification element. ${ }^{27,46}$ 

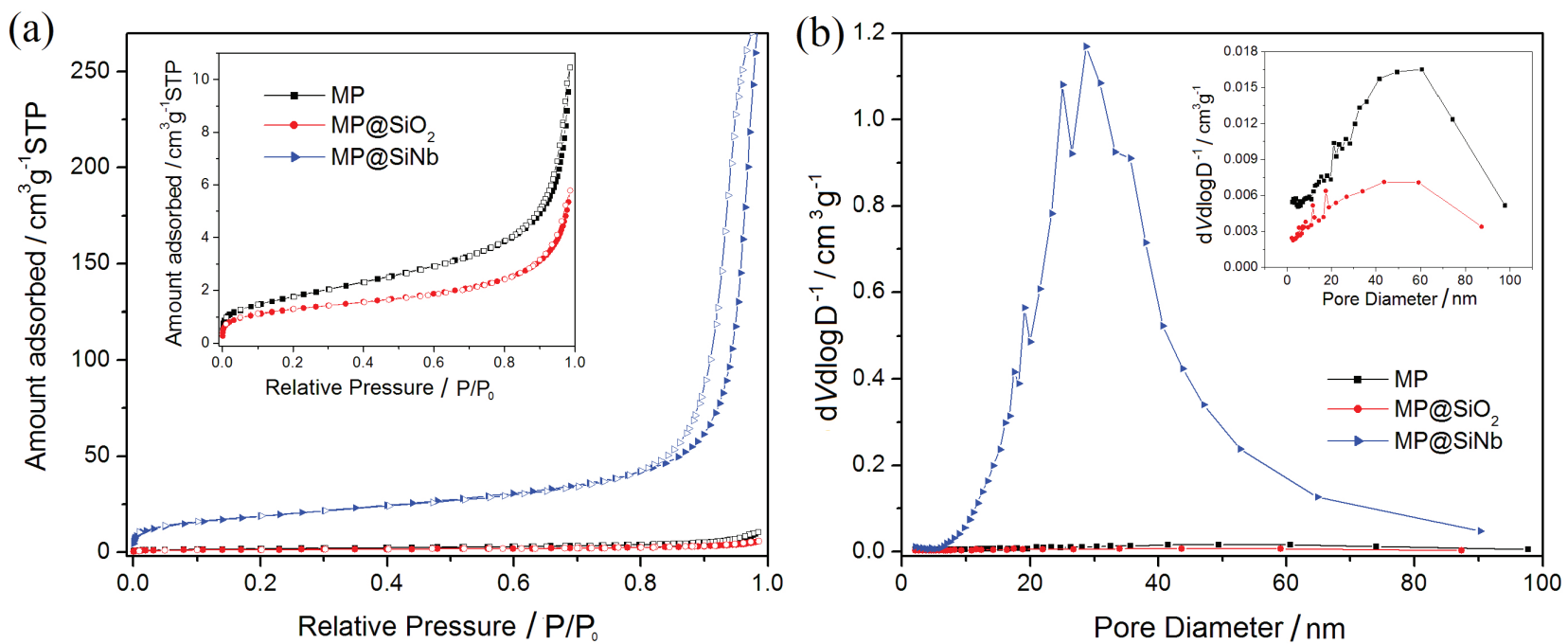

Figure 2. Textural analysis of materials. (a) $\mathrm{N}_{2}$ adsorption-desorption isotherms; (b) BJH pore size distribution curves.

Table 1. Textural analysis

\begin{tabular}{lcc}
\hline Sample & $\begin{array}{c}\text { BET surface area / } \\
\left(\mathrm{m}^{2} \mathrm{~g}^{-1}\right)\end{array}$ & $\begin{array}{c}\text { BJH pore volume / } \\
\left(\mathrm{cm}^{3} \mathrm{~g}^{-1}\right)\end{array}$ \\
\hline $\mathrm{MP}$ & $6.5 \pm 0.3$ & $0.015 \pm 0.001$ \\
$\mathrm{MP} @ \mathrm{SiO}_{2}$ & $4.4 \pm 0.3$ & $0.008 \pm 0.001$ \\
$\mathrm{MP} @ \mathrm{SiNb}$ & $68 \pm 3$ & $0.422 \pm 0.001$ \\
\hline
\end{tabular}

BET: Brunauer-Emmett-Teller; BJH: Barrett-Joyner-Halenda; MP: magnetite particles.

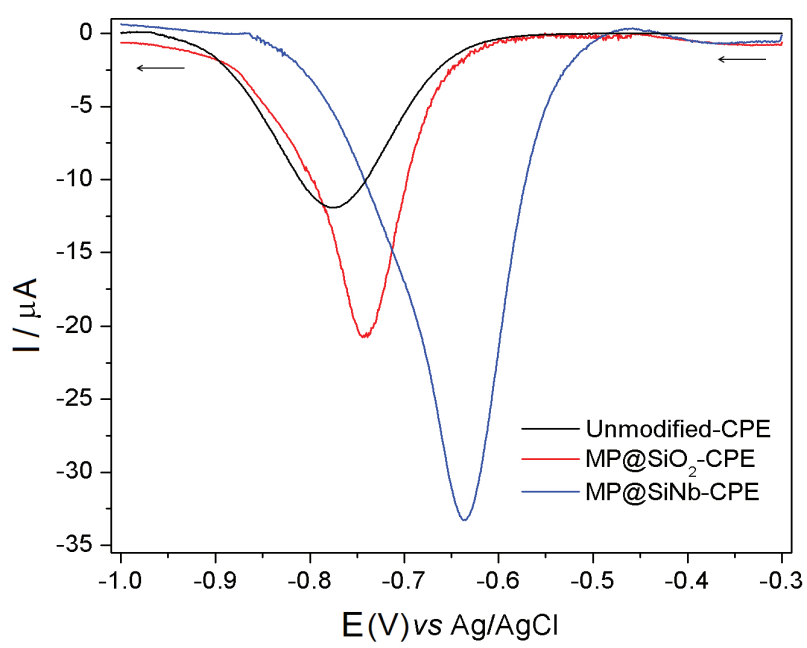

Figure 3. Differential pulse voltammograms of $p$-NP $\left(117.9 \mu \mathrm{mol} \mathrm{L} \mathrm{L}^{-1}\right)$ at unmodified-CPE, MP@ $\mathrm{SiO}_{2}-\mathrm{CPE}$ and $\mathrm{MP} @ \mathrm{SiNb}-\mathrm{CPE}$, in supporting electrolyte solution $\left(0.04 \mathrm{~mol} \mathrm{~L}^{-1}\right.$ of BRbs, $0.5 \mathrm{~mol} \mathrm{~L}^{-1}$ of $\left.\mathrm{NaNO}_{3}\right)$ at $\mathrm{pH}=6.0$.

Morever, the textural properties of the silica-niobia xerogel, as surface area and mesoporosity, improve the electroactive area and make easier the diffusion of the analytes, enabling their access to the active surface sites. ${ }^{44,47-49}$ In addition, due to the reported ${ }^{50,51}$ Brønsted and Lewis acidities of niobia-silica systems, they have affinity with phenols. ${ }^{52}$
This interaction should facilitate the reduction process of $p$-NP at the electrode/solution interface.

Aiming to achieve the optimized composition of the MP@SiNb-CPE, several electrodes were prepared by using different proportions of MP@SiNb material, graphite and mineral oil. The proportions are presented in the Supplementary Information (Table S2). The differential pulse voltammograms obtained for these electrodes in the presence of $p$-NP are shown in the Supplementary Information (Figure S4). Considering the current intensity, it is possible to observe that the best analytical response was obtained by means of an electrode prepared with the following composition: MP@SiNb (9 mg), graphite $(11 \mathrm{mg})$ and mineral oil $(5 \mathrm{mg})$. Also, the peak potential of the voltammogram slightly shifted to more positive values using electrode with the above composition. Therefore, this composition was applied in further measurements. In addition, the MP@SiNb-CPE electrochemical behavior was investigated at different $\mathrm{pH}$ values, aiming to find the optimal $\mathrm{pH}$ condition. The differential pulse voltammograms were recorded over a $\mathrm{pH}$ range from 3 up to 8 in the presence of $39.4 \mu \mathrm{mol} \mathrm{L} \mathrm{L}^{-1}$ of $p$-NP. The obtained results are presented in Figure 4, and gradual enhancing in the peak current of reduction is clearly observed with the increase of $\mathrm{pH}$ from 3 to 7 . No significant changes in the current value were detected at $\mathrm{pH} 8$, but the peak became broader. Because of this, $\mathrm{pH} 7$ was chosen as the optimal $\mathrm{pH}$.

To evaluate the analytical applicability of MP@SiNb-CPE, differential pulse voltammograms were obtained in BRbs with successive additions of $p$-NP. The voltammograms are presented in Figure 5. A well-defined peak of reduction at $-0.67 \mathrm{~V}$ is clearly seen and a linear 


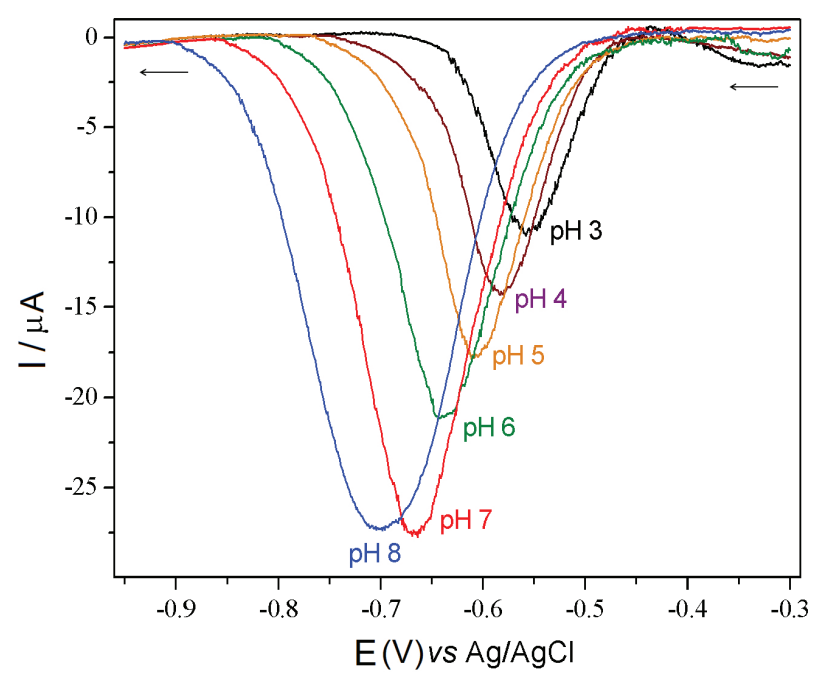

Figure 4. Differential pulse voltammograms of $p$-NP $\left(39.4 \mu \mathrm{mol} \mathrm{L}^{-1}\right)$ with MP@SiNb-CPE varying the $\mathrm{pH}$, using BRbs.

dependence between $p$-NP concentration and peak current was reached in two ranges: from 10 to $170 \mu \mathrm{mol} \mathrm{L}^{-1}$ and from 170 to $490 \mu \mathrm{mol} \mathrm{L}^{-1}$, which are expressed by the calibration plot inset Figure 5. The current peak intensities $\left(I_{\mathrm{pc}}\right)$ were obtained by subtracting the background current. The respective equations are:

$\mathrm{I}_{\mathrm{pc}}(\mu \mathrm{A})=-3.35(\mu \mathrm{A})-0.60\left(\mu \mathrm{A} \mathrm{L} \mu \mathrm{mol}^{-1}\right) \times$

$\left.[p-\mathrm{NP}](\mu \mathrm{mol} \mathrm{L})^{-1}\right), \mathrm{R}^{2}=0.9986$

$\mathrm{I}_{\mathrm{pc}}(\mu \mathrm{A})=-50.6(\mu \mathrm{A})-0.32\left(\mu \mathrm{A} \mathrm{L} \mu \mathrm{mol}^{-1}\right) \times$

$\left[p\right.$-NP] $\left(\mu \mathrm{mol} \mathrm{L}{ }^{-1}\right), \mathrm{R}^{2}=0.9971$

where $\mathrm{R}^{2}$ is the determination coefficient.

The estimated sensitivities obtained from the slope of the equations 1 and 2 were 0.60 and $0.36 \mu \mathrm{A} \mathrm{L} \mu \mathrm{mol}^{-1}$, respectively. The limit of detection (LOD) was calculated using the $\mathrm{LOD}=3 \times \mathrm{SD} /$ sensitivity ratio, where $\mathrm{SD}$ is the standard deviation obtained from the measurements of the blank solution $(n=8)$, the value obtained for the LOD was $1.2 \mu \mathrm{mol} \mathrm{L} \mathrm{L}^{-1}$. The limit of quantification (LOQ) was also calculated using the $10 \times \mathrm{SD} /$ slope ratio and the value found was $4 \mu \mathrm{mol} \mathrm{L}{ }^{-1}$. Table 2 presents the concentration range for $p$-NP determination and the LOD for other recent reports that use different kinds of electrodes. As it can be seen in the Table 2, the reached limit of detection for $p$-NP determination with MP@SiNb-CPE was comparable with the best reported sensors and presented a wide linear range of application. Therefore, the electrode MP@SiNb-CPE is very promising to be applied as sensor in the $p$-NP determination.

The repeatability or intraday precision ${ }^{67}$ of the MP@SiNb-CPE was estimated. Four experiments were performed in a single day, in the same electrochemical cell, using the same electrode. Afterwards, the intermediate

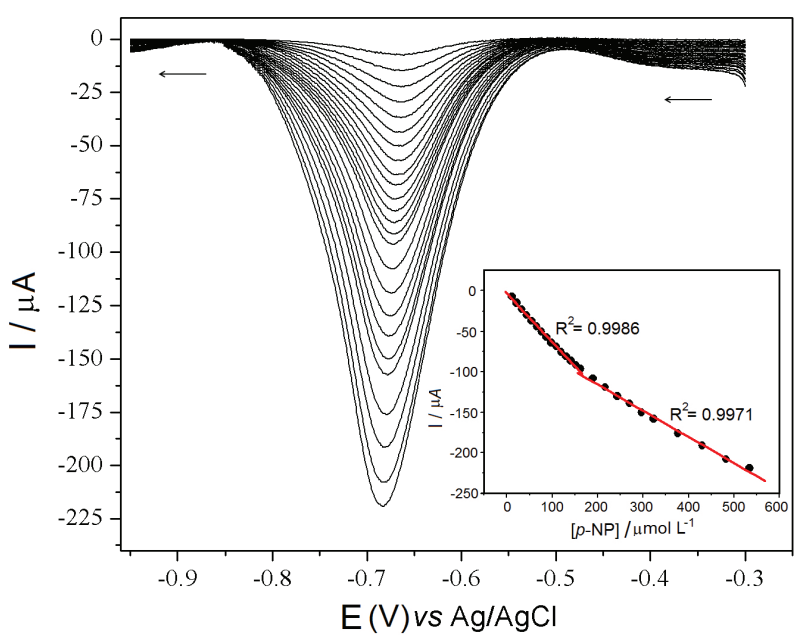

Figure 5. Differential pulse voltammograms of $p$-NP with MP@ SiNb-CPE in $0.04 \mathrm{~mol} \mathrm{~L}^{-1} \mathrm{BRbs}, \mathrm{pH} 7.0$, and $0.5 \mathrm{~mol} \mathrm{~L}^{-1}$ of $\mathrm{NaNO}_{3}$. Inset: linear correlation between peak current and $p$-NP concentration.

precision $^{67}$ was evaluated using the same electrode, the same cell, but over five different days. The differential pulse voltammograms are presented in the Supplementary Information, in Figures S5 and S6, respectively. As it can be clearly seen, no marked changes can be detected, and the relative standard deviations of peak current measurements were $0.44 \%$ for the experiments made in a single day and $0.83 \%$ for experiments performed on different days. The intermediate precision among different MP@SiNb$\mathrm{CPE}$ electrodes was also evaluated. Four electrodes were prepared in the same way and the differential pulse voltammograms are depicted in the Supplementary Information (Figure S7). A relative standard deviation of $1.8 \%$ was observed for peak current measurements. Therefore, the MP@SiNb-CPE electrode presents good characteristics of intraday and intermediate precisions that enable its use in the $p$-NP determination.

In order to apply the MP@SiNb-CPE electrode in real environmental samples, the selectivity was evaluated by probing some possible interfering phenolic compounds (2-bromophenol, 4-bromophenol, 2-aminophenol and hydroquinone, which are shown in Supplementary Information (Figure S8a) as well as other interferents such as $\mathrm{Cu}^{2+}, \mathrm{Zn}^{2+}, \mathrm{Ni}^{2+}$ or $\mathrm{Mn}^{2+}$ metal ions, on the detection of $78.6 \mu \mathrm{mol} \mathrm{L}{ }^{-1} p$-NP. The results indicate that concentrations of 2-bromophenol, 4-bromophenol, 2-aminophenol and hydroquinone 600-fold higher than that of $p$-NP did not interfere in its determination, since no detectable changes in the peak current could be observed. However, for 2 -aminophenol the limit concentration was 100-fold higher, considering the tolerance limit of interferents as $5 \%$ in the peak current intensity. ${ }^{68}$ The influence of 2-nitrophenol $(o-\mathrm{NP})$ is presented in Supplementary Information (Figure S8b), where no influence can be observed in 
the peak current of $p$-NP, in low concentrations of $o$-NP $\left(<76 \mu \mathrm{mol} \mathrm{L}{ }^{-1}\right)$. For $\mathrm{Cu}^{2+}, \mathrm{Zn}^{2+}, \mathrm{Ni}^{2+}$ or $\mathrm{Mn}^{2+}$ metal ions 12,000 -fold higher concentrations did not interfere in the $p$-NP determination.

As a way of demonstrating the viability of using the MP@SiNb-CPE electrode for real samples, $p$-NP determination was applied in tap water and also in fresh water collected from Guaíba Lake in Porto Alegre City. The water samples were spiked with known amounts of $p$-NP. The standard addition method was employed to estimate the recovery. The lake sample was filtered before analyzing, while the tap water was used as collected. The obtained results are presented in Table 3. The excellent recoveries for different concentrations indicate that the MP@SiNb-CPE electrode is appropriate to be applied in the analysis of $p$-NP in real samples.

Table 2. Parameters of electrochemical sensors for $p$-NP obtained from recent reports

\begin{tabular}{|c|c|c|c|}
\hline Electrode & Linear range $/(\mu \mathrm{mol} \mathrm{L}-1)$ & Limit of detection / $\left.(\mu \mathrm{mol} \mathrm{L})^{-1}\right)$ & Reference \\
\hline $\mathrm{GCE} / \mathrm{rGO}^{\mathrm{a}}$ & $50-800$ & 42 & 53 \\
\hline $\mathrm{rGO}-\mathrm{Ag} / \mathrm{GCE}^{\mathrm{b}}$ & $1-1100$ & 0.32 & 54 \\
\hline $\mathrm{Ni}-\mathrm{Co}_{\mathrm{OX}} \mathrm{NPs} / \mathrm{GCE}^{\mathrm{c}}$ & $7-682$ & 4.8 & 55 \\
\hline $\mathrm{MnONPs} / \mathrm{BCA} / \mathrm{Au}^{\mathrm{d}}$ & $200-550$ & 15.7 & 56 \\
\hline TLISS/GCE ${ }^{e}$ & $\begin{array}{c}1.4-55.9 \\
55.9-553.7\end{array}$ & 1.1 & 57 \\
\hline MIP-PANI/GO-CPE ${ }^{\mathrm{f}}$ & $60-140$ & 20 & 58 \\
\hline AcSCD-AuNPs-MC ${ }^{g}$ & $\begin{array}{c}0.1-10 \\
10-350\end{array}$ & 3.6 & 13 \\
\hline ITO/PANI ${ }^{\mathrm{h}}$ & $250-1400$ & 2 & 59 \\
\hline $\mathrm{BiFe}^{\mathrm{i}}$ & $1.0-100$ & 3.4 & 60 \\
\hline vAuE-AgNPj & $1-200$ & 5 & 61 \\
\hline FA-rGO ${ }^{k}$ & $2-140$ & 0.65 & 62 \\
\hline AcSCD-AuNPs-MC ${ }^{1}$ & $0.1-350$ & 3.63 & 13 \\
\hline $\mathrm{NiO}-\mathrm{CeO}_{2} / \mathrm{GCE}^{\mathrm{m}}$ & $1-20$ & 2.48 & 63 \\
\hline bPGE/AgAPs ${ }^{n}$ & $1-100$ & 1.5 & 64 \\
\hline $\mathrm{BSO}-\mathrm{gCN}^{\circ}$ & $1.6-50$ & 1 & 65 \\
\hline GDYO/GCE & $0.6-692$ & 0.2 & 66 \\
\hline MP@SiNb-CPE & $\begin{array}{c}10-170 \\
170-490\end{array}$ & 1.2 & this work \\
\hline
\end{tabular}

${ }^{a}$ Glassy carbon electrode modified with reduced graphene oxide; ${ }^{b}$ glassy carbon electrode modified with grapheme oxide and silver nanoparticles; ${ }^{\mathrm{c}}$ glassy carbon electrode modified with nickel-cobalt oxide nanoparticle; dgold electrode modified with manganese oxide nanoparticles and butyl carbitol acetate; eglassy carbon electrode modified with tremella-like indium silver sulfide; ${ }^{\mathrm{f}}$ molecularly imprinted polyaniline/graphene oxide carbon paste electrode; ${ }^{g}$ mesoporous carbon modified with per-6-deoxy-per-6-(2-carboxy-methyl)thio- $\beta$-cyclodextrin (AcSCD) and gold nanoparticles; ${ }^{\mathrm{h}}$ polyaniline films on indium doped tin oxide glass substrate working electrode; ${ }^{\mathrm{i} g l a s s y}$ carbon electrode modified with bismuth film deposition; ${ }^{\mathrm{j}}$ vapor deposition gold filmAgNP; kfulvic acid reduced graphene oxide glassy carbon electrode; ' ${ }^{1}$ cyclodextrin-decorated gold nanoparticle-mesoporous carbon glassy carbon electrode; ${ }^{\mathrm{m}}$ glassy carbon electrode modified with binary oxide; "pyrolytic graphite electrode modified with silver amalgam particles; ${ }^{\circ}$ barium stannate-graphitic carbon nitride nanocomposite; ${ }^{p}$ graphdiyne oxides/glassy carbon electrode.

Table 3. Determination of $p$-NP by MP@SiNb-CPE $(n=3)$ in real water samples

\begin{tabular}{|c|c|c|c|c|}
\hline Sample & Added / $\left(\mu \mathrm{mol} \mathrm{L}{ }^{-1}\right)$ & Found / $\left(\mu \mathrm{mol} \mathrm{L} \mathrm{L}^{-1}\right)$ & Recovery / \% & $\mathrm{RSD}^{\mathrm{a}} / \%$ \\
\hline \multirow{4}{*}{ Tap water } & 0 & not detected & - & - \\
\hline & 20 & 20.3 & 101.5 & 1.3 \\
\hline & 100 & 102 & 102.0 & 1.7 \\
\hline & 200 & 198 & 99.0 & 2.1 \\
\hline \multirow{4}{*}{ Lake water } & 0 & not detected & - & - \\
\hline & 20 & 20.4 & 102.0 & 1.5 \\
\hline & 100 & 103.5 & 103.5 & 2.0 \\
\hline & 200 & 196 & 98.0 & 2.4 \\
\hline
\end{tabular}

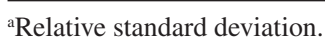




\section{Conclusions}

A mesoporous magnetic silica/niobia xerogel containing embedded spherical magnetite particles, which present ca. $330 \mathrm{~nm}$ of diameter, was successfully obtained. This magnetic material (MP@SiNb) is composed by $\mathrm{Fe}_{3} \mathrm{O}_{4}$ (ca. $\left.25 \% \mathrm{~m} / \mathrm{m}\right), \mathrm{SiO}_{2}$ (ca. $42 \% \mathrm{~m} / \mathrm{m}$ ) and $\mathrm{Nb}_{2} \mathrm{O}_{5}$ (ca. $\left.33 \% \mathrm{~m} / \mathrm{m}\right)$. It presents large mesopores in the range from 20 to $50 \mathrm{~nm}$ and a significant surface area of $68 \mathrm{~m}^{2} \mathrm{~g}^{-1}$. These interesting characteristics arise from both the composition and the planned strategy for the xerogel synthesis, which allow the material be applied in the construction of carbon paste electrode (MP@SiNb-CPE) for $p$-nitrophenol determination.The MP@SiNb-CPE was successfully applied as a sensitive and selective electrode for $p$-nitrophenol determination in real water samples.

\section{Supplementary Information}

Supplementary information is available free of charge at http://jbcs.sbq.org.br as PDF file.

\section{Acknowledgments}

The authors thank to FAPERGS, CNPq, CAPES and the Ministry of Education and Science of Ukraine for financial support and grants. The authors also thank NANO-UFRGS and CMM-UFRGS for facilities.

\section{Author Contributions}

Oleg S. Tkachenko was responsible for the conceptualization, investigation, methodology and writing original draft; Danielle S. da Rosa for the investigation and formal analysis; Anike $\mathrm{H}$ Virgili for the investigation and data curation; Marcos A. Z. Vasconcellos for the resources; Tania M. H. Costa for the funding acquisition, resources, writing review and editing; Leliz T. Arenas for the methodology, formal analysis and data curation; Monique Deon for the methodology, writing review and editing; Edilson V. Benvenutti for the funding acquisition, project administration and resources; Eliana W. de Menezes for the conceptualization, funding acquisition, methodology, supervision, writing review and editing.

\section{References}

1. Tiwari, J.; Tarale, P.; Sivanesan, S.; Bafana, A.; Environ. Sci. Pollut. Res. 2019, 26, 28650.

2. Karim, F.; Fakhruddin, A. N. M.; Rev. Environ. Sci. Bio/Technol. 2012, 11, 261 .
3. Ju, K.-S.; Parales, R.; Microbiol. Mol. Rev. 2010, 74, 250.

4. Zhou, X.; Liu, L.; Bai, X.; Shi, H.; Sens. Actuators, B 2013 , 181,661 .

5. Hammani, H.; Boumya, W.; Laghrib, F.; Farahi, A.; Lahrich, S.; Aboulkas, A.; El Mhammedi, M. A.; Mater. Today Chem. 2017, 3, 27.

6. Pan, B.; Chen, X.; Pan, B.; Zhang, W.; Zhang, X.; Zhang, Q.; J. Hazard. Mater. 2006, 137, 1236.

7. Tchieno, F. M. M.; Tonle, I. K.; Rev. Anal. Chem. 2018, 37, 20170019.

8. Tang, J.; Zhang, L.; Han, G.; Liu, Y.; Tang, W.; J. Electrochem. Soc. 2015, 162, 269.

9. Zhang, T.; Lang, Q.; Yang, D.; Li, L.; Zeng, L.; Zheng, C.; Li, T.; Wei, M.; Liu, A.; Electrochim. Acta 2013, 106, 127.

10. Karimi-Maleh, H.; Karimi, F.; Rezapour, M.; Bijad. M.; Farsi, M.; Beheshti, A.; Shahidi, S.; Curr. Anal. Chem. 2019, 15, 410.

11. Shahid, M. M.; Rameshkumar, P.; Huang, N. M.; Ceram. Int. 2015, 41, 13210 .

12. Zhou, Y.; Zhao, J.; Li, S.; Guo, M.; Fan, Z.; Analyst 2019, 144, 4400.

13. Mulaba-Bafubiandi, A. F.; Karimi-Maleh, H.; Karimi, F.; Rezapour, M.; J. Mol. Liq. 2019, 285, 430.

14. Xu, Y.; Wang, Y.; Ding, Y.; Luo, L.; Liu, X.; Zhang, Y.; J. Appl. Electrochem. 2013, 43, 679.

15. Caldas, E. M.; de Menezes, E. W.; Pizzolato, T. M.; Dias, S. L. P.; Costa, T. M. H.; Arenas, L. T.; Benvenutti, E. V.; J. Sol-Gel Sci. Technol. 2014, 72, 282.

16. Marco, J. P.; Borges, K. B.; Tarley, C. R. T.; Ribeiro, E. S.; Pereira, A. C.; J. Electroanal. Chem. 2013, 704, 159.

17. da Silva, D. N.; Tarley, C. R. T.; Pereira, A. C.; Electroanalysis 2017, 29, 2793.

18. Walcarius, A.; Chem. Soc. Rev. 2013, 42, 4098.

19. Walcarius, A.; Electroanalysis 2001, 13, 701.

20. Deon, M.; Caldas, E. M.; Rosa, D. S.; de Menezes, E. W.; Dias, S. L. P.; Pereira, M. B.; Costa, T. M. H.; Arenas, L. T.; Benvenutti, E. V.; J. Solid State Electrochem. 2015, 19, 2095.

21. Arenas, L. T.; Gay, D. S. F.; Moro, C. C.; Dias, S. L. P.; Azambuja, D. S.; Costa, T. M. H.; Benvenutti, E. V.; Gushikem, Y.; Microporous Mesoporous Mater. 2008, 112, 273.

22. de Souza, L. V.; Tkachenko, O.; Cardoso, B. N.; Pizzolato, T. M.; Dias, S. L. P.; Vasconcellos, M. A. Z.; Arenas, L. T.; Costa, T. M. H.; Moro, C. C.; Benvenutti, E. V.; Microporous Mesoporous Mater. 2019, 287, 203.

23. Francisco, M. S. P.; Cardoso, W. S.; Gushikem, Y.; J. Electroanal. Chem. 2005, 574, 291.

24. Francisco, M. S. P.; Cardoso, W. S.; Kubota, L. T.; Gushikem, Y.; J. Electroanal. Chem. 2007, 602, 29.

25. Rosatto, S. S.; Sotomayor, P. T.; Kubota, L. T.; Gushikem, Y.; Electrochim. Acta 2002, 47, 4451. 
26. Silveira, G.; de Morais, A.; Villis, P. C. M.; Maroneze, C. M.; Gushikem, Y.; Lucho, A. M. S.; Pissetti, F. L.; J. Colloid Interface Sci. 2012, 369, 302.

27. Morawski, F. M.; Deon, M.; Nicolodi, S.; de Menezes, E. W.; Costa, T. M. H.; Dias, S. L. P.; Benvenutti, E. V.; Arenas, L. T.; Electrochim. Acta 2018, 264, 319.

28. Hasanzadeh, M.; Shadjou, N.; Pournaghi-Azar, M. H.; Jouyban, A.; J. Electroceram. 2016, 37, 85.

29. Schneid, A. C.; Quevedo, A. B.; Pereira, M. B.; Araújo, P. F.; Franco, N.; Machado, G.; Moro, C. C.; de Menezes, E. W.; Costa, T. M. H.; Benvenutti, E. V.; Nanotechnology 2019, 30, 065604.

30. Park, H.; Lee, D.; Song, T.; J. Power Sources 2019, 414, 377.

31. Jayakumar, G.; Irudayaraj, A. A.; Raj, A. D.; Opt. Quantum Electron. 2019, 51, 312.

32. Kershi, R. M.; Ali, F. M.; Sayed, M. A.; J. Adv. Ceram. 2018, 7, 218.

33. Laranjo, M. T.; Morawski, F. M.; Dias, S. L. P.; Benvenutti, E. V.; Arenas, L. T.; Costa, T. M. H.; J. Braz. Chem. Soc. 2019, 30, 2660.

34. Kreissl, H. T.; Li, M. M. J.; Peng, Y.-K.; Nakagawa, K.; Hooper, T. J. N.; Hanna, J. V.; Shepherd, A.; Wu, T.-S.; Soo, Y.-L.; Tsang, S. C. E.; J. Am. Chem. Soc. 2017, 139, 12670.

35. Zaki, M. I.; Hasan, M. A.; Al-Sagheer, F. A.; Pasupulety, L.; Colloids Surf., A 2001, 190, 261.

36. Xu, X.; Liu, Z.; Zhang, X.; Duan, S.; Xu, S.; Zhou, C.; Electrochim. Acta 2011, 58, 142.

37. Xu, G.; Yang, L.; Zhong, M.; Li, C.; Lu, X.; Kan, X.; Microchim. Acta 2013, 180, 1461.

38. Naikoo, G. A.; Dar, R. A.; Khan, F.; J. Mater. Chem. A 2014, $2,11792$.

39. Hayat, A.; Rhouati, A.; Mishra, R. K.; Alonso, G. A.; Nasir, M.; Istamboulie, G.; Marty, J. L.; Int. J. Environ. Anal. Chem. 2016, 96, 237.

40. Dal Magro, L.; de Moura, K. S.; Backes, B. E.; de Menezes, E. W.; Benvenutti, E. V.; Nicolodi, S.; Klein, M. P.; Fernandez-Lafuente, R.; Rodrigues, R. C.; Biotechnol. Rep. 2019, 24, e00373.

41. Deon, M.; de Andrade, R. C.; Nicolodi, S.; da Cunha, J. B. M.; Costa, T. M. C.; Rodembusch, F. S.; de Menezes, E. W.; Benvenutti, E. V.; Part. Part. Syst. Charact. 2018, 35, 1800160.

42. Gregg, S. J.; Sing, K. S. W. In Adsorption, Surface Area and Porosity, $2^{\text {nd }}$ ed.; Academic Press: London, England, 1982.

43. Deon, M.; Morawski, F. M.; Passaia, C.; Dalmás, M.; Laranja, D. C.; Malheiros, P. S.; Nicolodi, S.; Arenas, L. T.; Costa, T. M. H.; de Menezes, E. W.; Benvenutti, E. V.; J. Sol-Gel Sci. Technol. 2019, 89, 333.

44. de Souza, L. V.; da Rosa, D. S.; Tkachenko, O. S.; Gomes, A. A.; Costa, T. M. H.; Arenas, L. T.; Benvenutti, E. V.; Ionics 2019, 25, 3259.

45. Radoń, A.; Drygała, A.; Hawełek, Ł.; Łukowiec, D.; Mater. Charact. 2017, 131, 148.
46. Hasanzadeh, M.; Shadjou, N.; de la Guardia, M.; TrAC, Trends Anal. Chem. 2015, 72, 1.

47. Walcarius, A.; Electroanalysis 2015, 27, 1303.

48. Caldas, E. M.; Novatzky, D.; Deon, M.; de Menezes, E. W.; Hertz, P. F.; Costa, T. M. H.; Arenas, L. T.; Benvenutti, E. V.; Microporous Mesoporous Mater. 2017, 247, 95.

49. Sánchez, A.; Morante-Zarcero, S.; Pérez-Quintanilla, D.; del Hierro, I.; Sierra, I.; J. Electroanal. Chem. 2013, 689, 76.

50. Umpierres, C. S.; Prola, L. D. T.; Adebayo, M. A.; Lima, E. C.; dos Reis, G. S.; Kunzler, D. D. F.; Dotto, G.; Arenas, L. T.; Benvenutti, E. V.; Environ. Technol. 2017, 38, 566.

51. Kondo, J. N.; Hiyoshi, Y.; Osuga, R.; Ishikawa, A.; Wang, Y.-H.; Yokoi, T.; Microporous Mesoporous Mater. 2018, 262, 191.

52. Canevari, T. C.; Arenas, L. T.; Landers, R.; Custodio, R.; Gushikem, Y.; Analyst 2013, 138, 315.

53. Wiench, P.; Grzyb, B.; González, Z.; Menéndez, R.; Handke, B.; Gryglewicz, G.; J. Electroanal. Chem. 2017, 787, 80.

54. Noor, A. M.; Rmeshkumar, P.; Yusoff, N.; Ming, H. N.; Sajab, M. S.; Ceram. Int. 2016, 42, 18813.

55. Asadpour-Zeynali, K.; Delnavaz, E.; J. Iran. Chem. Soc. 2017, 14, 2229.

56. Kumar, V.; Singh, K.; Panwar, S.; Mehta, S. K.; Int. Nano Lett. 2017, 7, 123.

57. Chen, P.; Shi, Y.; Li, X.; Wang, T.; Zhou, M.; Tian, E.; Wang, W.; Jiang, H.; Shu, H.; Int. J. Electrochem. Sci. 2018, 13, 6158.

58. Saadati, F.; Ghahramani, F.; Shayani-jam, H.; Piri, F.; Yaftian, M. R.; J. Taiwan Inst. Chem. Eng. 2018, 86, 213.

59. Ahmad, K.; Mobin, S. M.; Mater. Res. Express 2019, 6, 085508.

60. Nuñez, R. N.; Betancourth, J. M.; Ortiz, P. I.; Pfaffen, V.; Ind. Eng. Chem. Res. 2019, 58, 12411.

61. Havranova, P.; Ligmajer, F.; Danhel, A.; Electroanalysis 2019, $31,1952$.

62. Zhang, Y.; Xie, Q.; Xia, Z.; Gui, G.; Deng, F.; J. Electrochem. Soc. 2019, 166, B1293.

63. Ahmad, N.; Alam, M.; Wahab, R.; Ahmad, J.; Ubaidullah, M.; Ansari, A. A.; Alotaibi, N. M.; J. Mater. Sci.: Mater. Electron. 2019, 30, 17643.

64. Sebest, P.; Fojt, L.; Ostatna, V.; Fojta, M.; Danhel, A.; Bioelectrochemistry 2019, 132, 107436.

65. Vinotha, S.; Sampathkumar, P.; Giribabua, K.; Pandikumar, A.; Ultrason. Sonochem. 2020, 62, 104855.

66. Zhang, Y.; Xie, Q.; Xia, Z.; Gui, G. F.; Deng, F.; J. Electroanal. Chem. 2020, 863, 114058.

67. Peters, F. T.; Drummer, O. H.; Musshoff, F.; Forensic Sci. Int. 2007, 165, 216.

68. Zeng, Y.; Zhou, Y.; Zhou, T.; Shi, G.; Electrochim. Acta 2014, 130,505 .

Submitted: June 28, 2020

Published online: November 4, 2020 